REVISTA X, Curitiba, volume 14, n.4,p. 158-183, 2019

\title{
O CORPO EM CENAS INICIAIS DE (RE)CONSTRUÇÃO DA SEXUALIDADE ENTRE HOMENS: UMA PERSPECTIVA QUEER DE LEITURA
}

The body in initial scenes of (re)construction of sexuality between men: a queer perspective of reading

RESUMO: Vivemos em um contexto de forte tensão discursiva, no qual, dentro dos parâmetros regulatórios das identidades sexuais e de gênero, há pessoas que importam e outras que não importam, porque são consideradas como estando fora dos limites da heteronormatividade. Logo, são necessárias práticas de pesquisas em estudos de linguagem que, em diálogo com o paradigma epistemológico queer, tomem como o objeto de reflexão a relação linguagem, sexualidade (e gênero), objetivando problematizar os aspectos a partir dos quais a linguagem está conectada e forja a sexualidade, assumindo, para tanto, a noção de performatividade. Perseguindo esse propósito, nesse contexto histórico-cultural, propomo-nos a analisar cenas de uma telenovela, objetivando entender como a enunciação corporal, em seus recursos semióticos, de dois homens adultos participa do desalinhamento da sexualidade, figurando uma reconstrução dos afetos, desejos e prazeres em fase adulta, compreendendo, assim, que a telenovela dá lições de sexualidade, entendida como um conjunto de efeitos produzidos nos corpos, nos comportamentos e nas relações sociais dos sujeitos por dispositivos sociais/discursivos.

PALAVRAS-CHAVE: Linguagem; Sexualidade; Performatividade; Telenovela; Linguística Queer.

\begin{abstract}
We live in a context of strong discursive tension, in which, within the regulatory parameters of sexual and gender identities, there are people who matter and others who do not matter because they are considered to be outside the limits of heteronormativity. Therefore, it is necessary to practice research in language studies that, in dialogue with the queer epistemological paradigm, take as the object of reflection the relation language, sexuality (and gender), aiming to problematize the aspects from which the language is connected and forges the sexuality, assuming the notion of performativity. In pursuit of this purpose, in this historical-cultural context, we propose to analyze scenes from a telenovela, aiming at understanding how the bodily enunciation of two adult men in the semiotic resources participates in the misalignment of sexuality, with a reconstruction of the affections, desires and pleasures in adulthood, thus understanding that the telenovela gives lessons of sexuality, understood as a set of effects produced in the bodies, in the behaviors and in the social relations of the subjects by social / discursive devices.
\end{abstract}

KEYWORDS: Language; Sexuality; Performativity; Telenovela; Queer Linguistics. 
REVISTA X, Curitiba, volume 14, n.4,p. 158-183, 2019

\section{INTRODUÇÃO}

O objetivo nessa reflexão, que discute acerca de "Língua, linguagens e diversidade de gênero" ${ }^{1}$, incluindo aí questões de sexualidade, é o de refletir sobre linguagem e sexualidade (e masculinidades), problematizando a ideia de "sexualidade" como intransitiva, pronta (KULICK, 2000), e pontuar, mesmo que brevemente, a necessidade de uma postura queer nos estudos linguístico-discursivos, semióticos de modo geral, em diálogo com outras reflexões por mim já desenvolvidas, a exemplo de "Linguística Queer: na luta discursiva, como/sobre prática de ressignificação" (SANTOS FILHO, 2017). Para isso, é realizada perspectiva queer de leitura, como uma sugestão dessa postura insurgente nos estudos da linguagem.

Nesse sentido, é importante considerar que a argumentação é a de que no contexto atual há uma forte tensão discursiva em torno das identidades sexuais e de gênero que possivelmente se estende para atitudes de violência (ou delas se origina?), seja violência simbólica e ou física, contra aqueles e aquelas que não importam segundo os parâmetros de uma heteronorma, os parâmetros de "inteligibilidade", nos quais há a expectativa de coerência interna entre sexo, gênero e sexualidade (BUTLER, 2003 [1990]). Desse modo, nessa compreensão, faz-se relevante refletirmos a respeito da possibilidade de práticas de pesquisa, ou dessas práticas já em desenvolvimento, nas quais os estudos em língua(gem) estão em diálogo com um paradigma queer (MISKOLCI, 2015; LEWIS et al., 2017).

Dessas considerações, trago a leitura de uma cena de uma telenovela ${ }^{2}$, na qual dois homens adultos, amigos e recém-separados de suas esposas interagem, e questiono o que acontece ali, naquele momento enunciativo entre eles. Nessa discussão, interessa interpretar a participação dos corpos desses dois homens na enunciação que realizam, com fundamentos nas reflexões de Goffman (2002 [1964]), sobre a órbita microecológica, e Bucholtz e Hall (2016), que nos leva a compreender que o corpo fornece uma "gramática" para a enunciação. Nessa leitura, a questão proposta é: De que maneira os corpos dos dois homens na cena da telenovela participam do alinhamento

\footnotetext{
${ }^{1}$ Essa discussão foi apresentada na mesa-redonda "Língua, linguagens e diversidade de gênero", no SEBSurdos (Congresso Internacional e Seminário de Educação Bilingue para Surdos), na Universidade do Estado da Bahia, em Salvador (BA), em 17 de maio de 2018. Minha participação se deu a partir do convite do professor doutor Danniel da Silva Carvalho, da UFBA. Agora, o texto escrito, como modulação da apresentação oral, participa desse dossiê "Visibilidades e (R)existência".

${ }^{2}$ A telenovela é "Sete Vidas", escrita por Lícia Manzo e Daniel Adjafre, narrativa baseada nas relações humanas, nos dramas do dia a dia, conforme explica Santana (2017), exibida no horário das 18h, na TV Globo, em 2015, com permissão para a faixa etária a partir dos 10 anos.
} 
REVISTA X, Curitiba, volume 14, n.4,p. 158-183, 2019

(ou realinhamento ou desalinhamento) da sexualidade? Alinhamento aqui é compreendido como a posição do "eu" em suas interações com o outro, consigo mesmo e com as ações comunicações em curso (GOFFMAN, 2002 [1979]). Para isso, a compreensão perpassa pelo entendimento de quais recursos não-verbais são mobilizados e qual a possível participação desses no processo enunciativo, entendendo que essas enunciações estão imbricadas a questões de sexualidade (e de gênero), compreendida como não intransitiva (KULICK, 2000), conforme já dissemos.

Nessa reflexão, o interesse é na relação linguagem e sexualidade, dialogando com as ideias de Kulick (2000). No entanto, o propósito não é o de estudar como gays e lésbicas falam, como foi e ainda é comum em muitos trabalhos que focalizam essa relação, pois nos afastamos da compreensão de que há uma linguagem (específica) para os LGBT+. A filiação é com a argumentação de Kulick (2000, p. 243) de que "a linguagem gay e lésbica não existe e não pode existir da maneira que é amplamente imaginada". Afastamo-nos dessa ideia porque essa perspectiva acaba reduzindo a sexualidade - o conjunto de efeitos (desejos, medos, fetiches, prazeres, vontades etc.) produzidos por dispositivos sociais/discursivos nos corpos e estendidos a comportamentos e relações sociais (FOUCAULT, 1988) - à identidade sexual, já que as pesquisas sobre essa relação analisam a linguagem instanciada nos discursos de pessoas que se identificam como gays e lésbicas, imaginando que está lá essa linguagem, os recursos linguístico-discursivos que estariam atrelados a cada orientação sexual. Por esse ângulo, a identidade sexual se daria como um estado completo, como um pacote, inclusive com um código linguístico-discursivo exclusivo. Está nessa crença uma perspectiva de generalização da sexualidade e da linguagem.

Diferentemente, preocupamo-nos em estudar, tal como propõe Kulick (2000), formas pelas quais a linguagem está ligada e constrói a sexualidade, entendendo que a sexualidade não é apenas a identidade sexual, a orientação sexual, mas que é constituída de práticas, de desejos, de medos, de fetiches e de diversos outros aspectos que figuram os modos sexuais (KULICK, 2000; MISKOLCI, 2017), aspectos que nos interessam interpretar na cena televisiva em análise. Logo, situamo-nos em uma abordagem conceitual e procedimental sustentada pela noção de performatividade (BUTLER, 2003 [1990]), na qual visamos investigar como certas práticas linguístico-discursivas, ou semióticas de modo geral, constroem interlocutores como gay, lésbica ou outra identidade sexual, problematizando, dessa maneira, linguagem e categorias identitárias sexuais (e de gênero). 
Por essa compreensão, não partimos da ideia de "ser", mas da "tornar-se", no sentido de que os sujeitos se materializam como LGBT+ através de formas de uso da linguagem, construindo histórica e culturalmente suas identidades. Conforme entendemos com Kulick (2000), na noção de performatividade, perpassando por Austin (1962), Butler (2003 [1990]) e Livia e Hall (1997), as pessoas ao usarem a língua(gem) realizam ações no mundo e constroem seus modos de viver/experienciar através das próprias enunciações. Nesse arcabouço epistemológico, as enunciações realizam ações porque são citações, repetições de enunciados/discursos anteriores, no sentido de que incorporam formas convencionais de linguagem, a partir das quais os sentidos propostos são tomados como obrigatórios, necessários de serem seguidos, válidos Mas é certo que muitas pessoas podem não seguir os significados propostos nos enunciados, sendo a ação e a identificação (sexual ou de gênero) não concretizadas, fato que abre espaço para outros sentidos, outros modos de reconhecimento e de viver. No tocante à sexualidade, os efeitos produzidos nos corpos e nos comportamentos podem fugir da regra, podem mudar, transitarem, se reconfigurarem, pois eles são transitivos (KULICK, 2017).

Antes, para essa discussão, algumas questões são importantes:

01) O que é esse contexto de tensão discursiva em torno das identidades sexuais e de gênero?

02) O que é essa postura queer nos estudos linguístico-discursivos?

03) De que modo essa postura queer favorece as práticas sociais e discursivas e ou vivências/experiências sexuais (e de gênero) no atual contexto?

Para atender a esse projeto de reflexão/leitura, incialmente damos uma resposta (direta) à questão 01, inserindo, assim, a cena da telenovela e sua leitura. Na sequência, ou ao longo do texto, assumo uma postura/leitura queer nos estudos linguísticodiscursivos, questão 02, analisando a enunciação corporal entre dois homens em (re)construção da sexualidade, e, para finalizar, respondo acerca da necessidade e da importância da queerização dos estudos em linguagem, questão 03.

\section{DIAS ATUAIS, GÊNERO, SEX(O)UALIDADE E O CONTEXTO DE TENSÃO DISCURSIVA}

Em nossos dias, está bem visível (e de modo mais incisivo) uma guerra discursiva na qual seu objeto de disputa está centrado nas indagações: "O que é ser homem?" e "O que é ser mulher?". Sendo assim, interessa-nos interpretar uma cena 
enunciativa que participa dessa luta discursiva, pois entendo que essa interpretação possibilita criar inteligibilidade sobre a vida em sociedade (MOITA LOPES, 2006) sobre linguagem e sexualidade e sobre o funcionamento discursivo dessa produção textual/enunciativa, filiando esse estudo à abordagem da interface língua(gem), gênero e sexualidade (SANTOS FILHO, 2012; 2015a; 2015b; 2017). Para melhor entendimento desse aspecto, vamos a um fato.

No ano de 2018, uma polêmica foi instaurada na cidade de Paulo Afonso, Bahia, tendo se espalhado por todo o quadrilátero sertanejo ${ }^{3}$. Uma loja da cidade publicizou, via outdoors, a campanha "Mãe é mãe", seu marketing através de uma homenagem ao dia das mães. Em um desses "grandes cartazes", trazia como imagem de pano de fundo a fotografia de um rapaz e o enunciado verbal "Umas usam saias, outras, barba", conforme podemos ver/ler!

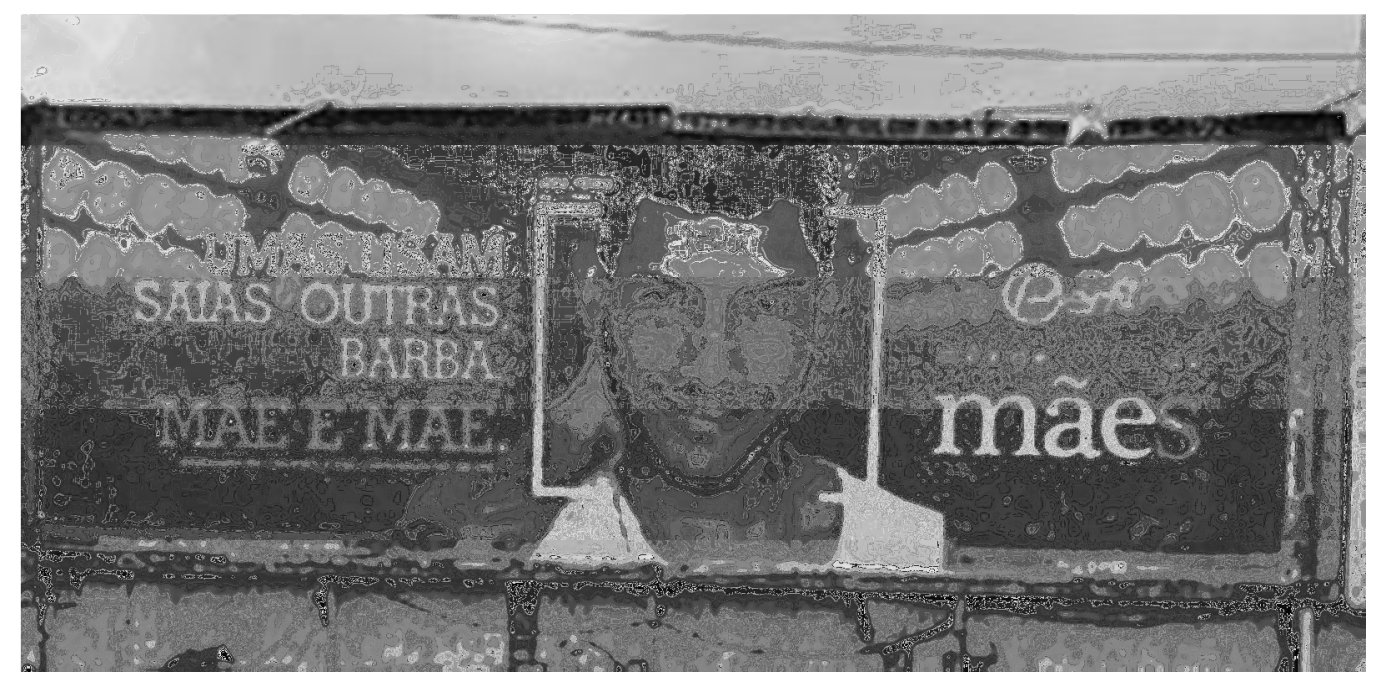

Figura 01: Fotografia do outdoor "Mãe é mãe"

Fonte: Loja Perfil (Paulo Afonso/BA).

Nesse contexto de uma guerra discursiva em torno das identidades sexuais e de gênero, a imagem de um homem atrelada à ideia/possibilidade de que mães, além de saias, podem usar barba foi o suficiente para que a polêmica fosse instaurada, porque, através do processo de metonímia, aquele em se toma a parte pelo todo, gerou-se a inferência de que saias refere-se a "mães mulheres" e barba a "mães homens". O outdoor foi retirado, devido a uma campanha de boicote à loja, mobilizada por um pastor, para quem "somente ao sexo feminino (XX) é possível a benção divina da

\footnotetext{
${ }^{3}$ Área de sertão que, formando um quadrilátero, envolve os estados de Alagoas, Pernambuco, Sergipe e Bahia.
} 
REVISTA X, Curitiba, volume 14, n.4,p. 158-183, 2019

maternidade", caracterizando a enunciação da loja como contrária à família, sendo, portanto, "uma afronta aos valores cristãos do sagrado matrimônio". Para o evangélico, a enunciação dá vida à ditadura gay: “o viado agora é mãe”. O que está nesse caso específico em disputa discursiva é o que é ser "mãe", o que é ser "mulher", envolvendo aspecto de sexualidade e de gênero.

Essa disputa se torna possível porque há grupos de sujeitos que entendem a vida por um viés biologizante-religioso, para o qual deve haver nas pessoas uma coerência produzida automaticamente entre os cromossomos e a materialidade sexual (as genitálias), o gênero e a sexualidade, gerando a masculinidade e a feminilidade (de modo essencial, universal e binário) e a heterossexualidade, como única sexualidade possível: é a inteligibilidade do gênero (e da sexualidade), a inteligibilidade do humano (BUTLER, 2003 [1990]). Nesses parâmetros regulatórios, a sexualidade é instinto, atributo genético e permanente nos sujeitos (FABRÍCIO e MOITA LOPES, 2008); é intransitiva, fixa (KULICK, 2000).

Segundo essa compreensão, os inteligíveis importam, sofrem luto, são o centro, a norma, conforme BUTLER (2003 [1990]) e Moita Lopes e Baynham (2017). Os nãoheterossexuais (gays, lésbicas, travestis, bissexuais, pessoas trans etc.) não importam, são pessoas não-válidas, porque são desviantes, são periféricos, matáveis (e não sofrem luto), porque são não-inteligíveis. Desse modo, os desejos e as afetividades tornam-se constrangidos por restrições morais político-culturais (MISKOLCI, 2017). Nesse contexto, certamente, é possível argumentar que a lei, a polícia e a medicina também constrangem os desejos e as afetividades, constrangem a sexualidade.

Assim, é possível afirmar que a cultura que tem a heterossexualidade como a norma está bem evidente em nosso país atualmente. É o que podemos denominar de "cultura heteronormativa”, ou "ditadura heteronormativa" (COLLING, 2015), na qual há recusas dos considerados não-inteligíveis, que são colocados em condição de precariedade, de risco (BUTLER, 2009). É um regime regulatório dos afetos, dos desejos e dos poros, os orifícios corporais. E, tal como afirma Pelúcio (2017, p. 12), "ainda hoje se humilha, agride e mata quem ousa viver fora da heteronorma". Essa cultura, tal como aprendemos em Butler (2003 [1990]; 2009) pode tornar-se "autoridade moral vinculante", isto é, pode ser vista como sentidos obrigatórios. Ou nela podem haver "insurgências", como resistência à polaridade centro-periferia para os desejos, as práticas e identidades sexuais, por exemplo. 
REVISTA X, Curitiba, volume 14, n.4,p. 158-183, 2019

Nas práticas insurgentes, as pessoas "subversivas" a essa cultura não almejam o “centro”, não querem o "centro", isto é, não querem ser "inteligíveis” (LOURO, 2008). Essas assumem uma postura contra a normalização, contra a heteronormalização, bem como uma postura contra a homonormatividade. É uma postura contra as normas e os controles aos modos de viver sexualidades e gêneros considerados não-válidos, postura contrária aos controles aos poros e aos desejos. Assim, por uma outra lógica, queer, o mundo é visto por uma perspectiva pós-estruturalista, na qual o sujeito - corpos e identidades - não está lá, na morfofisiologia dos corpos, é, ao contrário, social, cultural, histórico e discursivo; é performativo.

Logo, nesse atual momento histórico, político e cultural, muitas das pessoas colocados em condição de "desvio" não a aceitam e têm tomado a enunciação de si, possibilitadas pelas tecnologias da informação e comunicação e pelas redes/mídias sociais digitais, tornando-se protagonistas; assumem agência, a exemplo da divulgação da música "Que delícia ser viado", de Gustavo Bezzi, que estourou no carnaval de 2017, que se propõe como um "grito de liberdade", ao mencionar o prazer de homens em se reconhecerem como homossexuais, viados. É possível dizer que nessa música há resistência, insurgência, indecência de uma "multidão queer" (PRECIADO, 2011):

\footnotetext{
Ai que delícia, que delícia ser viado Vamo ser pra sempre ser viado é babado! Taca mais viado que tá pouco eu quero é mais! Taca mais viado que tá pouco taca mais, e vai! Toda gatinha, toda afeminada e vai, e vai, e vai Patrícia vai!
}

Nesse bojo de questões, interessa-nos, nos estudos em língua(gem), dialogar com a perspectiva queer, pós-estruturalista, estranhando as noções de língua(gem) e os arranjos linguísticos/semióticos em "projetos performativos" (disfarçados de projetos de representação). Ou seja, pautado na ideia de performatividade (BUTLER, 2003 [1990], LÍVIA e HALL, 1997; KULICK, 2000), entendemos que toda e qualquer enunciação não mostra o objeto de seu discurso, mas que, ao contrário, inventa aquele objeto. Por isso, mesmo que imaginemos que o texto representa/aponta um (suposto) referente anterior, tal como uma sexualidade, já lá instaurada nos corpos dos sujeitos, a enunciação está propondo sentidos de modo a construir aquilo sobre o que fala. Nesse sentido, poderíamos estranhar os arranjos linguístico-discursivos realizados no outdoor em homenagem ao dia das mães, focalizando a palavra "mãe", queerizando a noção de língua(gem) pressuposta na enunciação no outdoor e na mobilização contrária proposta 
pelo pastor através de seu enunciado. Eis uma postura queer, ao estranhar/problematizar os semas ${ }^{4}$ para a palavra "mãe”, estabelecendo relação do uso linguístico com questões de gênero e sexualidade. Mas, esse não é o foco aqui e agora!

\section{ÓRBITA MICROECOLÓGICA E ENUNCIAÇÃO INCORPORADA EM CENAS DE "SETE VIDAS"}

Conforme já pontuamos, a leitura aqui desenvolvida é de uma cena da telenovela "Sete Vidas", exibida no último capítulo dessa narrativa televisiva, em 2015, pela TV Globo, na qual os personagens Renan e Eriberto (vividos pelos atores Fernando Eiras e Fábio Herford, respectivamente), dois homens adultos, amigos e recém-separados de suas esposas, iniciam interação de desejos afetivos e sexuais entre si. Esses diálogos são aqui compreendidos como um processo inicial de (re)construção, em fase adulta, da sexualidade masculina, da identidade sexual de cada um. Nessa discussão, interessa interpretar a participação dos corpos desses dois homens na performatização da sexualidade: desejos, medos etc. Na leitura, a questão proposta é: De que maneira os corpos dos dois homens na cena televisiva participam do alinhamento da sexualidade (ou realinhamento ou desalinhamento)?, sendo o objetivo compreender quais recursos não-verbais são mobilizados e qual a possível participação desses no processo enunciativo.

$\mathrm{Na}$ discussão, a cena da telenovela é entendida como discurso midiático, na condição de dispositivo pedagógico, visto que educa os corpos, levando os sujeitos a se identificarem ou a se desidentificarem com os sentidos propostos, na ideia de que as significações se dão numa pedagogia. Assim, a análise focaliza a orbita microecológica (GOFFMAN, 2002 [1964]) da cena estudada, a enunciação incorporada e a sintaxe televisiva (SANTOS FILHO, 2016), pelo conceito de performatividade (BUTLER, 2003 [1990]; SANTOS FILHO, 2015b), que põe em foco o processo de "citação", efetivando-se, tal como já discutimos na introdução.

\footnotetext{
${ }^{4}$ Entendemos que as palavras são formadas por elementos menores significativos, os morfemas. Algumas, como no caso de "mãe", são formadas por um único morfema, bem como "flor", por exemplo. Cada morfema por sua vez, a princípio, é constituído de um "semema", que é a significação a ele atrelada/proposta. O semema é constituído por vários "semas", as partículas elementares de significado, conforme nos explica Bizzocchi (2014). Em "mãe", podemos ter o semema de "fêmea que tem/teve/cria/cuida/protege filho(a)s", mas esse é constituído de outras partes elementares, tais como "fêmea animal", "mulher", "aquela que teve filho(a)s", "aquela que cria filho(a)s", "aquela que cuida de filho(a)s", podendo ser também "aquele que cuida/protege filho(a)s". No caso do outdoor, na enunciação "umas usam saias, outras, barba", o sema para a palavra "mãe" é "quem cuida e protege", distanciando-se, portanto, do sema "mulher".
} 
REVISTA X, Curitiba, volume 14, n.4,p. 158-183, 2019

Inicialmente, é relevante entendermos que a cena de telenovela é aqui estudada como um gênero discursivo mediado, pois suportado pela TV, no qual há a oralização de um roteiro, ou a "performance" de atores a partir de um roteiro, construindo uma conversa face a face, cotidiana, entre dois homens adultos. Se acaso não considerássemos que essa é uma cena televisiva, ficaríamos apenas com a ideia de conversa cotidiana. Essa compreensão possibilita-nos a análise do corpus por dois vieses, quais sejam, inicialmente na condição de conversa cotidiana e, na sequência, como cena televisiva de telenovela, figurando, assim, um esquema didático para a análise.

Para essa leitura, estamos considerando o conceito de órbita microecológica, de Goffman (2002 [1964]), no qual as nossas conversas cotidianas, as interações face a face, emergem de uma situação de enunciação. Assim, é essa situação de enunciação que denominamos de órbita microecológica, no sentido de que, numa enunciação face a face o que conta como válido não são as categorias sociais (como algo fixo), mas os valores, os alinhamentos, ou posicionamentos, sobre essas categorias no instante da enunciação. Ou seja, a órbita microecológica não é o contexto, como espaço de fatos e objeto passível de descrição direta, mas o ambiente humano e material que se constitui como esfera de ação, instituindo um jogo complexo de ação e interpretação de sua ação e das da interlocução.

Na enunciação face a face ocorre a "gestão de si" de maneira situada, na qual as ações corporais são constitutivas dessa enunciação, a partir de valores aceitos e considerados justos. Assim, a enunciação é a participação verbo-corporal, ou só corporal, no jogo complexo de interação, gerando um alinhamento, posicionamento, acerca de determinado objeto de disputa, ou realinhamento, ou desalinhamento em relação a esse e frente ao posicionamento do outro, o interlocutor, dentro de determinada cultura. Nesse sentido, os significados propostos para si e para a interlocução são/estão incorporados, constituindo o corpo, constituindo os sujeitos na interação. Nessa compreensão, o corpo produz a linguagem e a linguagem produz o corpo (BUCHOLTZ e HALL, 2016). Essa perspectiva dialoga com a noção de performatividade, para a qual as práticas discursivas constroem ações, forjam os sujeitos, corpos, sexualidade e gênero. Mas, como esse processo se efetiva? Partindo de Bucholtz e Hall (2016), podemos estender essa noção e entender que o corpo produz a linguagem e a linguagem produz, por sua vez, desejos, sexualidade e gênero (BUTLER, 2003 [1990]). 
REVISTA X, Curitiba, volume 14, n.4,p. 158-183, 2019

Essa compreensão interessa à(o) linguista queer, aquele/aquela com propósitos de realizar práticas de pesquisa de ressignificação nos estudos linguístico-discursivos, subvertendo conhecimentos linguísticos "bem-comportados" e saberes fundados na compreensão biologizante da vida, de modo a problematizar a interface língua(gem), sex(o)ualidade e gênero (SANTOS FILHO, 2017). Essa compreensão interessa à Linguística Queer porque é subversiva, porque assume uma perspectiva pósestruturalista, em relação à linguagem e em relação aos corpos, aos desejos, aos prazeres, às práticas desejantes e sexuais, aos gêneros; aos sujeitos. É uma abordagem necessária ao atual contexto de uma luta discursiva em relação às identidades sexuais e de gênero. Vamos à leitura da cena da telenovela.

\section{O CORPO, SUA LINGUAGEM E A PRODUÇÃo dO AFETO, DO DESEJO E DO PRAZER ENTRE HOMENS}

Na cena que segue, os dois homens estão sentados em poltronas de um cinema assistindo a um filme. Para os telespectadores/as telespectadoras da telenovela, eles são amigos, mesmo após as últimas cenas em que apareceram, em capítulos anteriores, denominadas aqui de Cena 01 e Cena 02, nas quais há índices discursivos, através da enunciação verbo-corporal, de que a relação entre eles pode ser outra, não apenas de amizade, mas de afetos e desejos sexuais. No momento inicial da cena no cinema, denominada aqui de Cena 03, exibida em 10 de julho de 2015, no capítulo 106, último capítulo da telenovela, entre 51'07' e 51'51', cena que recebe nossa atenção de análise, ao assistirem ao filme, no enquadramento mostrado pela imagem fixa adiante, os dois homens não se olham, como podemos perceber.

O olhar deles é lançado para a frente, ao mesmo tempo em que esboçam um leve sorriso e demonstram semblantes calmos. Um deles, Renan (à esquerda), deixa sua cabeça levemente inclinada em direção ao amigo, Eriberto (à direita). Que citações fazem ao não se olharem, olharem para frente, esboçarem leve sorriso, apresentarem semblantes calmos e cabeças inclinadas? Que performatização estão realizando? Será que tais gestos corporais são em decorrência de estarem em um ambiente "público"? Tais questões ajudam-nos a pensar sobre a órbita microecológica dessa interação. 


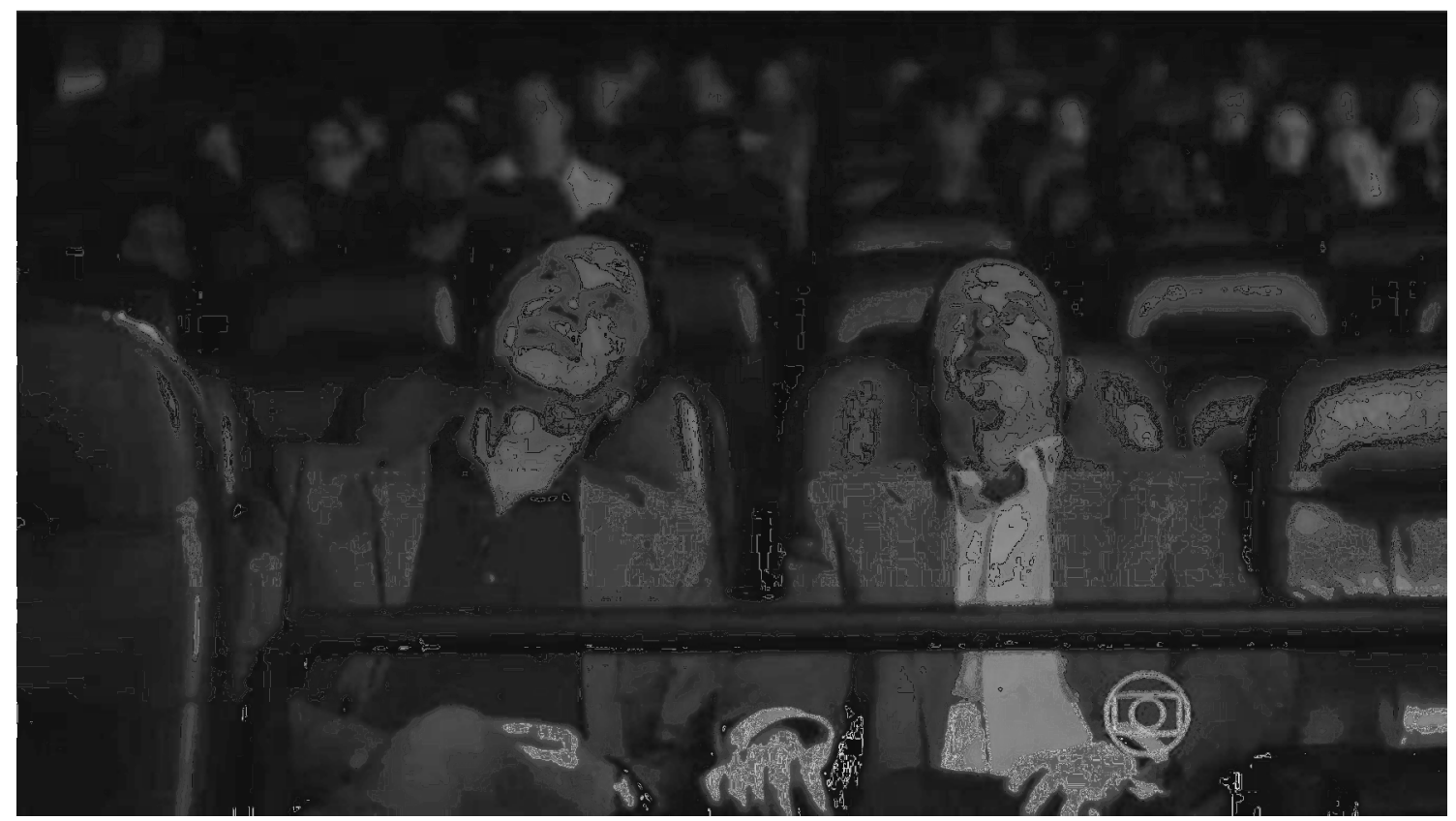

Figura 02: Momento inicial da Cena 03: Renan e Eriberto no cinema. Fonte: Sete Vidas (TV Globo), Cap. 106, 2015.

No entanto, no decorrer da cena, Renan lança o olhar para contemplar Eriberto (à direita), com um leve sorriso. Em seguida, a cabeça e o olhar são direcionados para a mão de Eriberto. Há em Renan um leve susto esboçado no semblante, que é imediatamente desfeito, sendo o olhar lançado para o horizonte novamente. Por essa descrição inicial, essa Cena 3 está recortada em 4 (quatro) partes, cada uma com diversos enquadramentos, sobre os quais se detém nossa leitura, como vemos na sequência desse tópico.

\section{Na órbita microecológica, as citações incorporadas e a performatização da sexualidade (e do gênero) - uma perspectiva queer de leitura}

De modo geral, podemos interpretar que nas 4 (quatro) partes da Cena 3, os dois homens, Renan (à esquerda) e Eriberto (à direita), utilizam-se do sorriso e do olhar, recursos não verbais cinésicos (DIONÍSIO, 2005). Inicialmente, os dois esboçam sorrisos leves e expressões de calma, de paz consigo mesmo. Renan, nas demais partes, constrói sua enunciação corporal com um leve sorriso, com o olhar de contemplação ao amigo, fazendo da mão dele seu "objeto" de observação. No entanto, no final da última parte, Renan esboça uma expressão de susto leve. Se considerarmos a cultura heteronormativa em que vivemos, faz-se necessário questionar: o que está acontecendo nessas partes da cena? Que "citações” foram realizadas/incorporadas pelos dois homens? 
Que performatização está sendo construída por Eriberto e Renan e, no final, por Renan? Será que a escolha pelo cinema para o encontro é apenas uma "desculpa" para expressarem um novo alinhamento sexual, ou um desalinhamento sexual, mesmo que apenas corporalmente? Estão aí atitudes ativas e passivas bem direcionadas a cada um dos amigos, já que nessa cena as atitudes são de iniciativa de Renan? O silêncio da verbalização de afetos e desejos entre os dois homens se dá pelo contexto enunciativo ser público? Esse silenciamento verbal estaria para as sexualidades que se distanciam da heteronorma?

Para realizar essa interpretação, faz-se importante saber que essa Cena 3 se configura como a confirmação de um encontro acordado entre esses dois homens, em cena anterior, a Cena 02, exibida no capítulo 105, em 09 de julho de 2015. Assim, para compreendermos melhor a Cena 3, é preciso que antes descrevamos essa cena anterior, a 2, na qual há um encontro, que havia sido proposto por Renan (à esquerda), visando conversar sobre a atitude de Eriberto (à direita) ter esboçado seus sentimentos, numa cena ainda anterior, a Cena 01, exibida no capítulo 104, em 08 de julho de 2015, transcrita na sequência. Nessa cena 01, a ação de Eriberto de falar de seus sentimentos pelo amigo deixou Renan possivelmente desconcertado, provocando certo distanciamento do amigo. Assim, para analisar a Cena 03, recorremos à compreensão de duas cenas anteriores, quais sejam, as denominadas aqui de Cena 01 e Cena 02. Depois, voltamos à Cena 03.

\section{Cena 01}

O que acontece na Cena 01 ? Na transcrição ${ }^{5}$ dessa cena, "R" é para Renan, à esquerda, e "E” é para Eriberto, à direita. A transcrição está também informada por duas imagens, uma do início do diálogo, na qual vemos os dois homens amigos sentados à mesa, em um restaurante, e outra do final do diálogo, na qual Renan encontra uma desculpa e abandona a conversa, afastando-se de Eriberto:

\footnotetext{
${ }^{5}$ A chave de sinais usada para a transcrição é a seguinte: i) barra inclinada para a direita (/) tem a função de indicar interrupção de palavras e truncamento de sentenças, ii) letras em caixa alta, a exemplo de “... boBOGEM..." indicam entoação enfática, fala mais alta, iii) dois pontos repetidos (::) indicam alongamento de fonemas, vogais ou consoantes, iv) hífen (-) indica silabação, v) sinal de interrogação (?) indica questionamento, vi) um sinal de adição entre parênteses (+) indica qualquer pausa, vi) três sinais de adição entre parênteses (+++) indicam uma pausa longa, vii) colchete virado para a esquerda ([) indica superposição de vozes, e viii) aspas (“"”) indicam citações literais.
} 


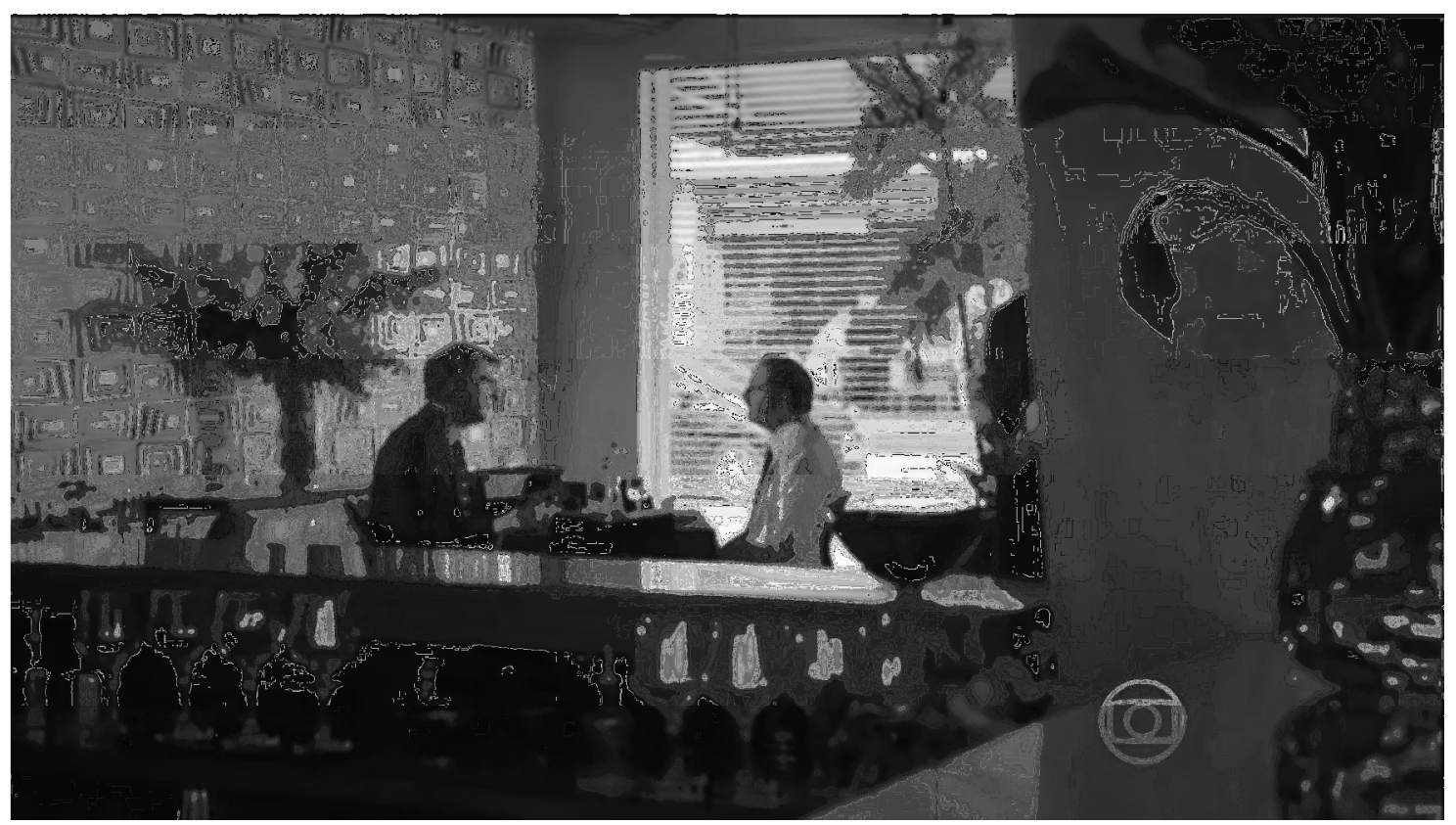

Figura 03: Momento inicial da Cena 01: Renan e Eriberto conversam em um restaurante. Fonte: Sete Vidas (TV Globo), Cap. 104, 2015.

07'40” R: $\quad$ pelo tom de sua voz $(+)$ eu $(+)$ eu deduzi que a coisa era grave mesmo $(+)$ e $(+++)$ mas diante disso $(+)$ porque que você não me ligou antes?

07'49” E: é que eu (+) eu me levei um tempo até que eu conseguisse me recobrar (+++) concatenar as ideias $(+)$ e (+) estar minimamente apresentável

07'58” R: $\quad$ bobagem $(+)$ diante dos grandes amigos podemos também mostrar nosso lado avesso (+) né? (+++) afinal (+) o que houve com marta (+) alguma coisa súbita?

08'08" E: na hora me pareceu que sim $(+)$ era vil $(+)$ truculento demais para ser verdade $(+)$ mas $(+)$ mas depois $(+)$ pensando melhor $(+)$ me surpreende não ter acontecido antes $(+++)$ não porque a distância entre nós fosse enorme $(+)$ isso não me assustava $(+)$ frequentemente as diferenças são complementa::res (+) enriquecedo::ras (+++) mas $(+)$ no nosso caso $(+)$ eram diferenças de valores $(+)$ de princípios $(+)$ e essas diferenças são intransponíveis

08'41" R: hum (+) eu entendo

08'44" E: $\quad$ ainda assim (+) talvez eu me obrigasse a permanecer (+) naquela prisão por anos $(+)$ não fosse a morte de papai me libertar

08'52” R: era tão pesada assim (+) para você (+) a expectativa de seu pai?

08'56" E: em absoluto (+) a presença de papai (+) sempre foi doce em minha vida (+) foi a ausência dele que $(+)$ que me disparou um alarme $(+)$ o fechar de olhos de papai $(+)$ abriu os meus pra determinadas coisas $(+)$ por exemplo $(+)$ a percepção do quanto a vida é fugaz (+) do quanto a vida pa::ssa (+) escorre entre os dedos (+) mais do que permanecer fiel ao meu casamento (+) eu me dei conta do quanto não sou fiel a mim mesmo (+++) e essa é a pior das traições

09'31" R: $\quad$ nada do que você viveu foi em vão (+) acredite (+) estou diante de um homem livre (+) corajoso $(+)$ a caminho do seu destino $(+++)$ a caminho de encontrar alguém que $(+)$ que possa dar valor a a a delicadeza dos seus sentimentos

09'49” E: na verdade $(+)$ renan $(+)$ eu acho que já encontrei $(+++)$ desculpe $(+)$ me perdoe se eu tiver $(+)$ pisando num terreno delicado ao falar sobre isso (+) mas/ mas a experiência de me sentir acolhido (+) de me sentir aceito (+) sem restrições $(+)$ sem nada a esconder ou a omitir (+) finalmente à vontade na frente do outro (+++) a alegria (+) de partilhar uma área $(+)$ um poema $(+)$ um/ um perfume exótico (+) tudo isso eu descobri que eu já tenho (+) a única coisa que falta saber (+) é se esse sentimento é recíproco

10’34” R: ah (+) desculpe-me (+) perdão (+) ai perdão 
$10 ’ 37 " \mathrm{E}$ :

eu estiver

eu é que peço perdão (+) se

10’38” R:

[

perdão (+) eu

10’39” E: é que peço perdão se eu estiver sendo íntimo (+) eu quero que você saiba (+) que essas/ que essas descobertas também me desconcertam (+) e você mais do que ninguém $(+)$ que/ que me conhece $(+)$ sabe que eu sou um homem tradicional

10'51" R:

[

se/ seja como for $(+)$ se/ seja o que for (+) é um movimento sincero (+) e/ e merece todo o respeito $(+)$ e $(+++)$ bem $(+)$ eu $(+)$ eu/ eu desejo a você $(+)$ meu amigo $(+)$ to/ toda a sorte do mundo $(+)$ nessa nova jornada $(+)$ e que ela te traga um $(+++)$ um $(+)$ esqueci $(+)$ esqueci $(+)$ esqueci de te dizer $(+)$ desculpe $(+)$ in::felizmente eu/ eu (+) infelizmente eu/ eu não tenho tempo $(+)$ eu tô/ eu tô com um $(+)$ eu/ eu tenho compromisso $(+)$ eu me esqueci de te dizer $(+)$ desculpe $(+)$ eriberto $(+)$ meu neto faz ano hoje $(+)$ francisco $(+)$ eu já te falei dele

11'33" E:

11'34" R:

11'39” E:

11"40" R: claro

[

faz aniversário (+)

mariinha está me esperando em casa $(+)$ porque nós vamos conversar com ele através do computador (+) e

\section{claro (+) fique à vontade $(+)$ claro}

não $(+)$ eu $(+)$ me desculpe $(+)$ é $(+)$ eu devia ter dito $(+)$ é $(+)$ bom $(+)$ é $(+)$ bom $(+)$ nós nos falamos $(+)$ né $(+)$ nos falamos $(+++)$ me desculpe $(+++)$ eu espero que você fique bem $(+)$ nós nos vemos $(+)$ né $(+)$ a qualquer momento $(+)$ a qualquer hora nós nos falamos $(+++)$ fique bem

Quadro 01: Transcrição da Cena 01

Fonte: Sete Vidas (TV Globo), Cap. 104, 2015.

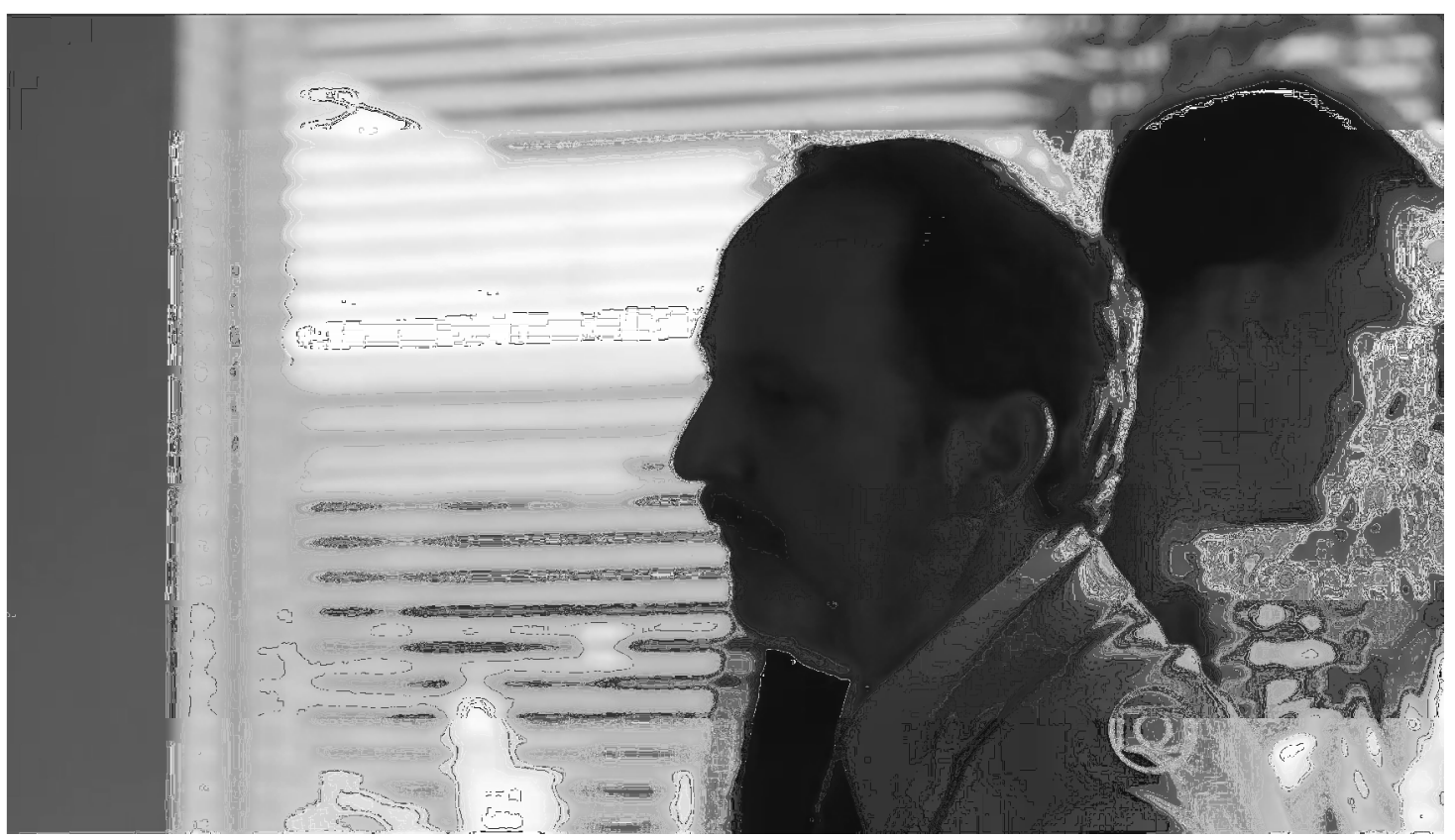

Figura 04: Momento final da Cena 01: Renan abandona a conversa com Eriberto.

Fonte: Sete Vidas (TV Globo), Cap. 104, 2015. 
REVISTA X, Curitiba, volume 14, n.4,p. 158-183, 2019

O que acontece na cena 01, transcrita anteriormente? Entendemos que Eriberto e Renan se encontram, a pedido de Eriberto, a quem Renan dá apoio, para que esse fale de sua separação de Marta, sua esposa. Esse assunto se torna o tópico da conversa, até 9'49", momento a partir do qual Eriberto redireciona o tópico de fala e esboça uma declaração de seu afeto pelo amigo Renan, que, diante daquela situação, fica nervoso, deixa a xícara cair sobre a mesa, em 10’34”, logo após Renan ter dito que já encontrou alguém que possa dar valor aos seus sentimentos, mas que "a única coisa que falta saber é se esse sentimento é reciproco", referindo-se a se sentir acolhido, aceito, sem restrições, à vontade, pelo amigo. Até esse momento, o diálogo entre eles é cheio de muitas pausas, leves e longas, marcando hesitações, trocas de olhares fixos, respirações profundas, figurando tensão entre os dois homens. A enunciação de Eriberto visa expor o que ele denomina de "descoberta", mas que nós podemos compreender como identificação com outras possibilidades afetivas. Ele está alinhando-se a outras possibilidades de relacionamento.

Após o momento da queda da xícara, que é o momento em que a fala de Eriberto se torna mais explícita quanto aos seus afetos em relação a Renan, as respirações são mais profundas, as palavras se tornam entrecortadas, há sobreposições de falas, indicando cortes um na fala do outro. Renan parece não querer saber dos sentimentos de Eriberto, que o interrompe para insistir em dizer de sua afeição. Há roubo de turnos, configurando nervosismo entre eles, constituindo tensão mais forte. Nitidamente Renan recusa-se a ouvir/participar daquela conversa com aquele tópico em discussão. Há um desalinhamento entre eles, pois se Eriberto está se identificando com outras possibilidades de afetos, isso certamente não ocorre com Renan, que, por isso, abandona a conversa, para decepção de Eriberto, que fica desolado, mas com a promessa, pelo amigo, de que se falarão. Renan solicita ao amigo que ficasse bem. Essa interpretação da cena, a partir da transcrição, e constituindo a transcrição, é possível porque os recursos linguísticos/semióticos usados estão disponíveis em nossa sociedade, convencionados, fato pelo qual podemos reconhecê-los e interpretá-los no contexto da órbita microecológica em questão. Tais recursos constituem-se como léxico dessa enunciação: a significação não se dá apenas pelos recursos linguísticos; a significação ganha movimento (DIONÍSIO, 2005). O que levou Eriberto a autonomear-se de "homem tradicional", como vemos na sequência, no trecho destacado, logo após a explícita recusa de Renan em continuar a conversa, conforme lemos a seguir? 
10’39” E: é que peço perdão se eu estiver sendo íntimo (+) eu quero que você saiba (+) que essas/ que essas descobertas também me desconcertam $(+)$ e você mais do que ninguém $(+)$ que/ que me conhece $(+)$ sabe que eu sou um homem tradicional

\section{Quadro 02: Transcrição de um trecho da Cena 01}

Fonte: Sete Vidas (TV Globo), Cap. 104, 2015.

Certamente a resposta ao questionamento anterior está no fato de, mesmo estando apenas os dois na enunciação, o que configura uma conversa reservada, o jogo enunciativo se torna complexo porque provavelmente paira sobre seus modos de ser, principalmente para Renan, nessa cena, o regime regulatório da inteligibilidade do humano, no qual esses sentimentos, afetos e sexo entre dois homens não podem existir. Assim, ao autonomear-se de "homem tradicional" está se construindo como homem, mas já "desconcertado" por suas "descobertas", por seus interesses por outro homem. Desse modo, não parece não transitar em seu gênero, apenas na sexualidade. Essa leitura já nos aponta para a relação não simples, nem direta, entre linguagem e sexualidade, essa não vista apenas como orientação sexual.

\section{Cena 02}

Há um novo encontro, na Cena 02, exibida no capítulo seguinte, 105, no dia 9 de julho de 2015, para que Renan informasse ao amigo que ficou afetado por ele ter falado de sua relação com a esposa como "falta de afinidade e de eternos desencontros". Renan afirma, respirando profundamente, que reconheceu ali traços do próprio casamento, no sentido de que, assim como Eriberto, também nutria "o desejo de uma vida nova", livre de ideias e regras que não eram deles. Vemos que, com a voz incisiva, com o olhar focado para Eriberto e com a respiração profunda, portanto, com seu corpo, Renan produz sentidos de que ficou "tocado" e "contaminado" com as palavras do amigo. Assim, parece estar se afastando do regime de controle da inteligibilidade. Verbal e corporalmente, Renan está se alinhando aos sentidos, ou melhor, aos sentimentos, propostos por Eriberto no último encontro. Os corpos de Renan e de Eriberto estão produzindo linguagem (verbal e não-verbal), significações; estão produzindo afetos entre si; estão produzindo outra possibilidade de sexualidade.

Sem mais tanto nervosismo e a tensão do encontro anterior (Cena 01), Renan diz, então, que está separado também de sua esposa, o que vai confirmando um desalinhamento à heteronorma, que se configura em um realinhamento dos afetos, e da 
sexualidade. Argumenta que poder contar com o apoio e a companhia de Eriberto é para ele algo muito valioso. Eriberto responde com um semblante alegre através de um sorriso. Renan realiza um convite para irem no final de semana ao cinema, assistir Charles Chaplin, porque, segundo defende, será uma oportunidade, ao assistir a um filme sem enunciação verbal, de contemplar um olhar, um gesto, um silêncio, que dizem mais do que mil palavras.

Renan, ao se referir ao filme, certamente, fazendo-se delicado, cavalheiro, falava a respeito deles, construía a si e a seu amigo; construía aquele momento, muito mais do que falar, de fato, a respeito do filme de Chaplin. Essa leitura é possível porque no momento final da cena, nesses 6 enquadramentos na sequência, é a contemplação do outro que eles constroem, com os olhos marejados de lágrimas, como vemos.

Figura 05: 06 enquadramentos finais da Cena 02.

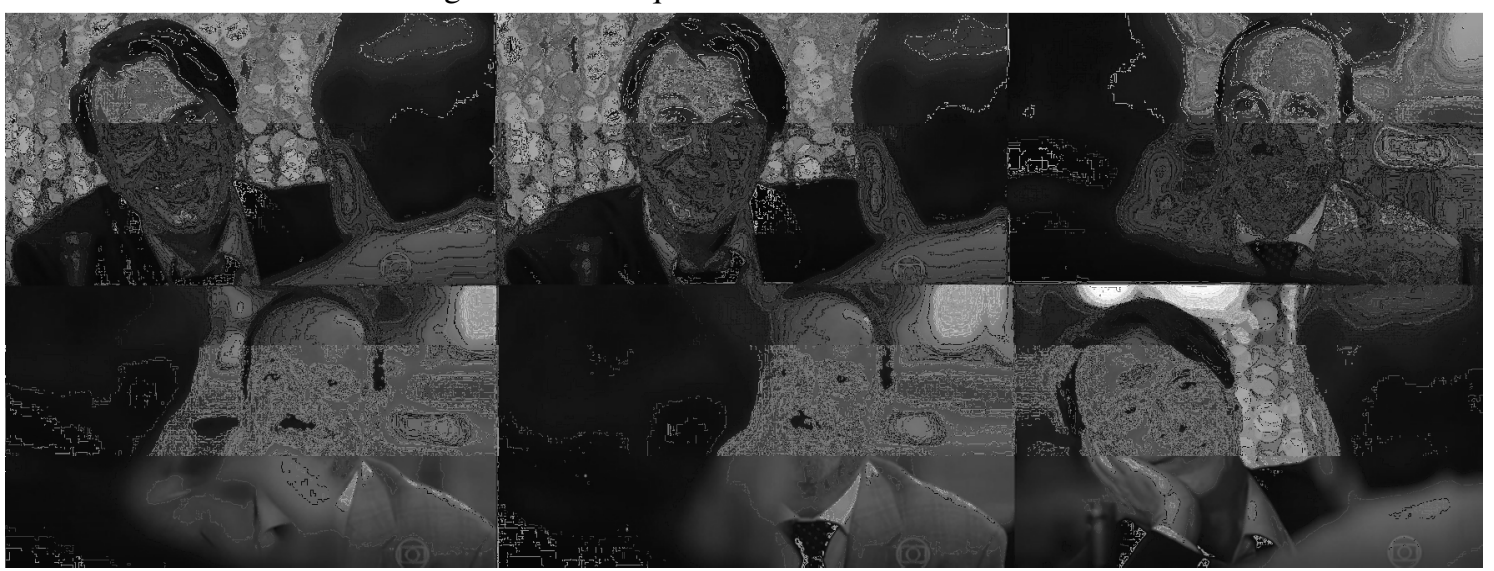

Fonte: Sete Vidas, Cap. 105, 2015.

São os sorrisos, ora mais expansivos ou mais leves, juntamente aos maneios da cabeça, por Renan (à esquerda), e das lágrimas mais evidentes, de Eriberto (à direta), que nos levam a interpretar que eles, no silêncio verbal, enunciam um ao outro, e para si mesmos (com o corpo), uma proximidade afetiva e, provavelmente, sexual entre eles. É a proposta da "vida nova" já anunciada. Dão início, de modo gentil, à construção de afetos (e desejos amorosos?), enunciados/construídos pelas linguagens verbal e corporal. Dessa maneira, nessa cena 02, constroem para si de maneira sutil a possibilidade de mobilidade do desejo sexual entre eles, entre dois homens adultos amigos, subvertendo o interesse apenas ao sexo oposto, ao qual estiveram filiados durante décadas de suas vidas, pois parecem esboçar um afastamento do que era a única possibilidade sexual, a heterossexualidade. Essas são citações, que se configuram como indícios semióticos, de que, de fato, estão em realinhamento da sexualidade, visto que em nossa cultura aos 
homens não está permitido nem o abraço entre, muito menos a troca de olhares e a contemplação. Nas lágrimas não há choro; é a emoção da permissão que estão se dando para novas experiências.

\section{Cena 03}

Assim, na Cena 03, no enquadramento 01, já mostrado em páginas anteriores, e com mais detalhes na sequência, na qual nos deteremos mais em nossa leitura, ao estarem sentados, assistindo ao filme, no cinema, com o olhar para frente, leve sorriso e semblante de calmaria, estão se alinhando na mesma proposta de significação costurada inicialmente na última conversa, Cena 02. Reconhecem-se nessa calmaria e leveza, a partir do esboço do sorriso leve e do semblante calmo, por juntos se possibilitarem a uma "nova vida", que significa uma nova experiência afetiva e sexual, já podemos assim compreender. Logo, podemos inferir que estão em/com seus corpos construindo derivas de seus desejos, derivas porque que em nossa cultura heteronormativa, o desejo e o sentimento afetivos e sexuais entre pessoas do mesmo sexo são constrangidos por restrições morais, conforme argumenta Miskolci (2017), bem como por restrições religiosas e policiais. Vejamos mais da Cena 03:

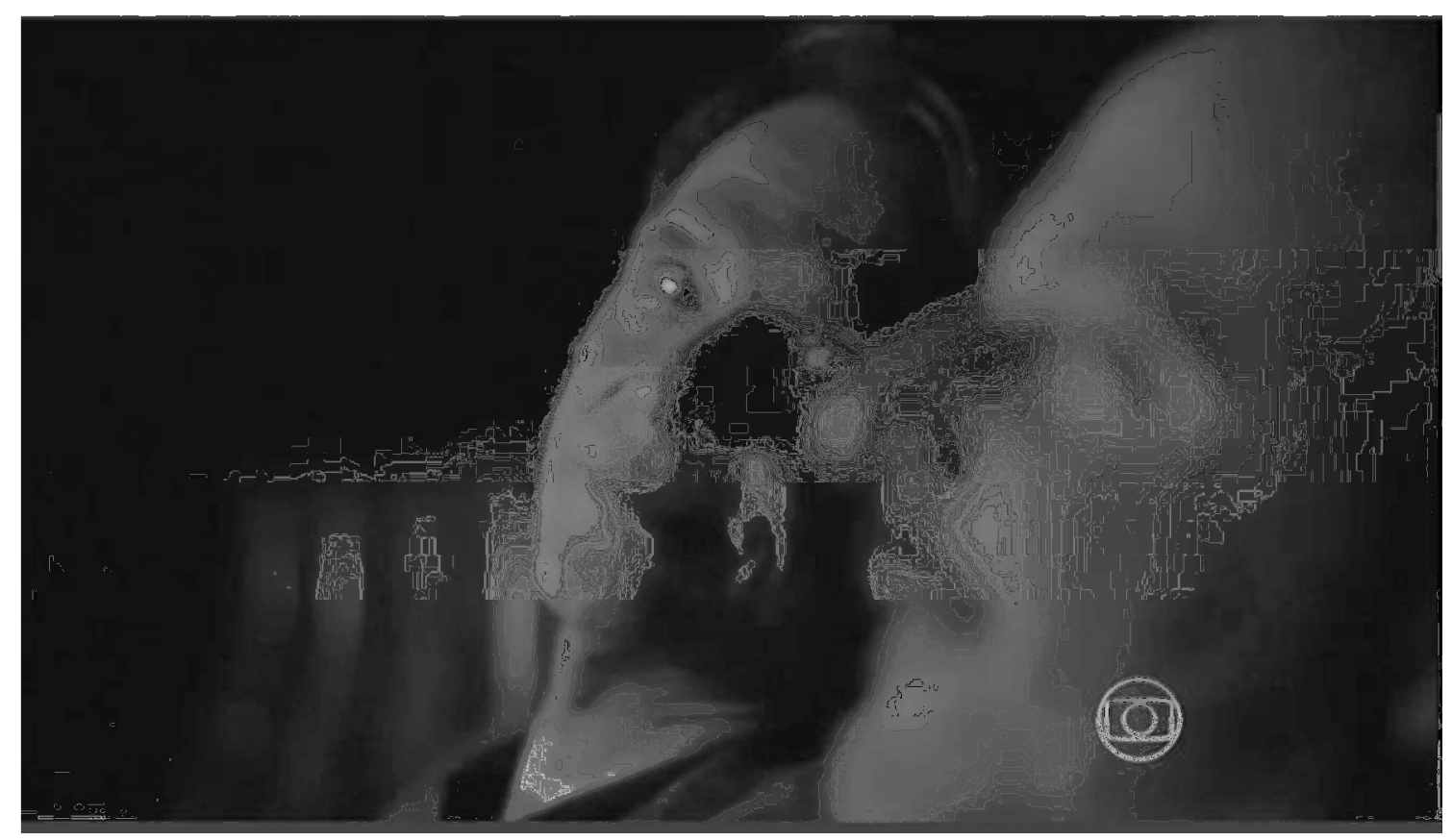

Figura 06: Recortes de 1 enquadramento da Cena 03.

Fonte: Sete Vidas, Cap. 106, TV Globo, 2015.

Nessa imagem anterior, enquadramento 02 , da Cena 03, no cinema, ao inclinar a cabeça para o lado, bem como seu olhar, para ver o amigo, de modo a contemplá-lo com 
um sorriso curto, bem como a realização da contemplação e o toque da mão dele, nos enquadramentos 03, 04 e 05, que seguem, Renan (à esquerda) possivelmente torna o outro seu sujeito/“objeto" de desejo. Agora, na órbita microecológica, sob a penumbra da sala de cinema, o desalinhamento à heteronorma vai ganhando forma. Nessa sequência de enquadramentos, Eriberto abre os dedos e Renan entrelaça seus dedos aos dele. Dessa maneira, se antes, na Cena 02, foram a visão de mundo e os interesses em comum que os aproximavam para a nova relação, agora é o corpo do outro, tomado pelo rosto e pela mão, como em processo de metonímia, aquele de tomar a parte pelo todo. Em outra sequência de enquadramentos 06, 07 e 08, mostradas também a seguir, Eriberto olha para as mãos entrelaçadas e esboça expressão de leve susto, engolindo a saliva ao final.
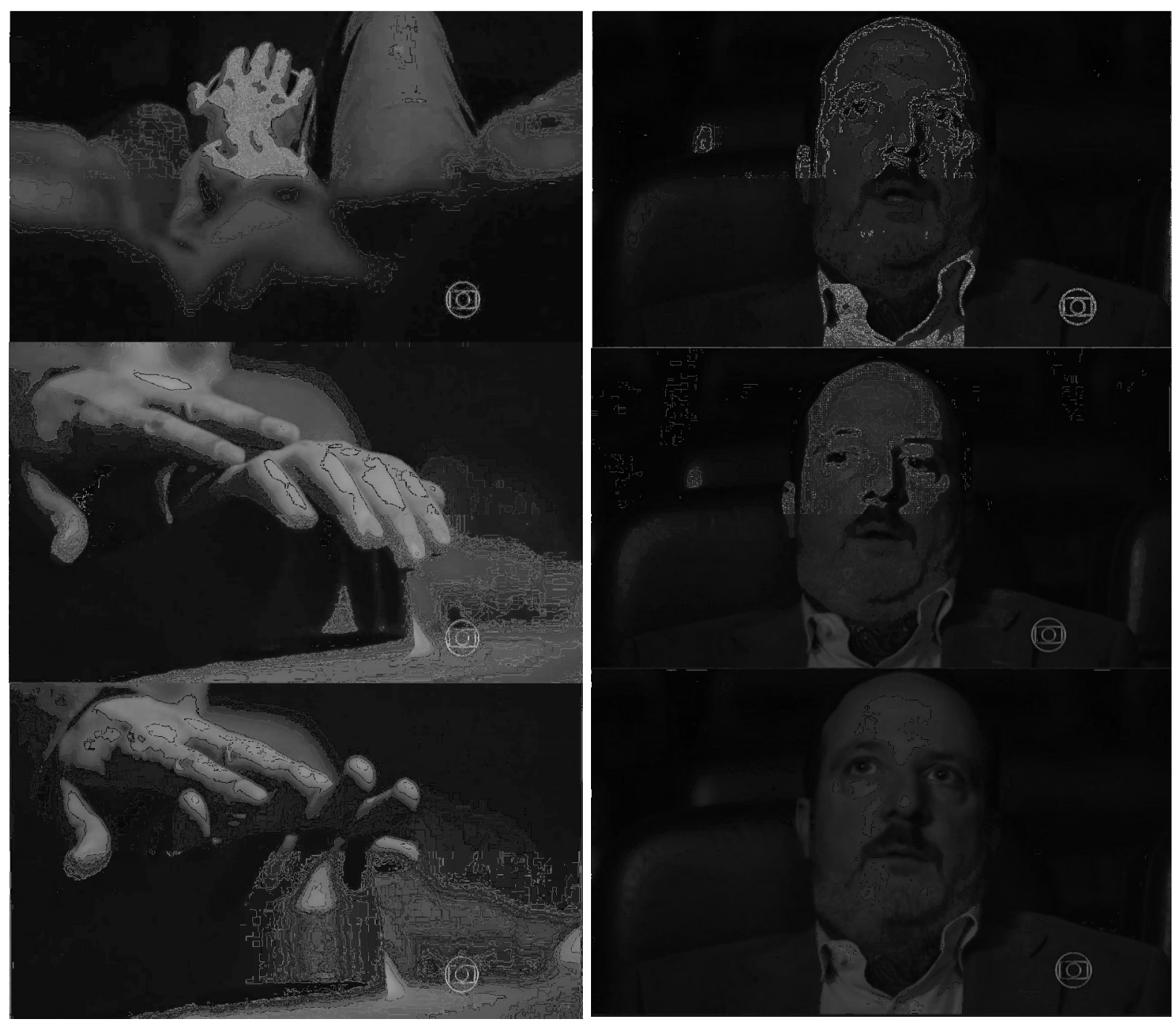

Figura 07: Enquadramentos de 03 a 08 da Cena 03.

Fonte: Sete Vidas, Cap. 106, TV Globo, 2015. 
No decorrer da cena, essa significação por Renan não é sem medo, pois, de repente, enuncia um leve susto, ao direcionar o olhar para a mão do, até então, amigo, como vemos na sequência de enquadramentos 09 a 14. Porém, o medo imediatamente se desfaz. Não há medo, não há traumas, pois continua alinhado às derivas do desejo. Entretanto, de que Renan poderia ter medo? Com certeza ele deve saber que está se afastando dos desejos considerados normais para um homem (adulto, avô, recémseparado, economicamente equilibrado). Está se afastando da heteronorma. Porém, esse fantasma regulatório não o impede, pois, Renan coloca sua mão esquerda sobre o braço direito de Eriberto e, na sequência, avança para a mão do amigo. Em continuidade da cena, Eriberto olha para o amigo. As mãos se entrelaçam e Renan engole saliva e expressa calma através do olhar. As mãos se tocam, se entrelaçam e se apertam. Ambos esboçam leve sorriso e expressão de paz, com o olhar direcionado para frente. Eriberto fecha os olhos! É a contemplação do desejo e do prazer por outro homem? São homossexuais? Bissexuais? Homens que fazem sexo com outro homem (HSH)? A categorização da orientação sexual depende do próprio sujeito e seu reconhecimento/identificação a uma identidade sexual (e de gênero).

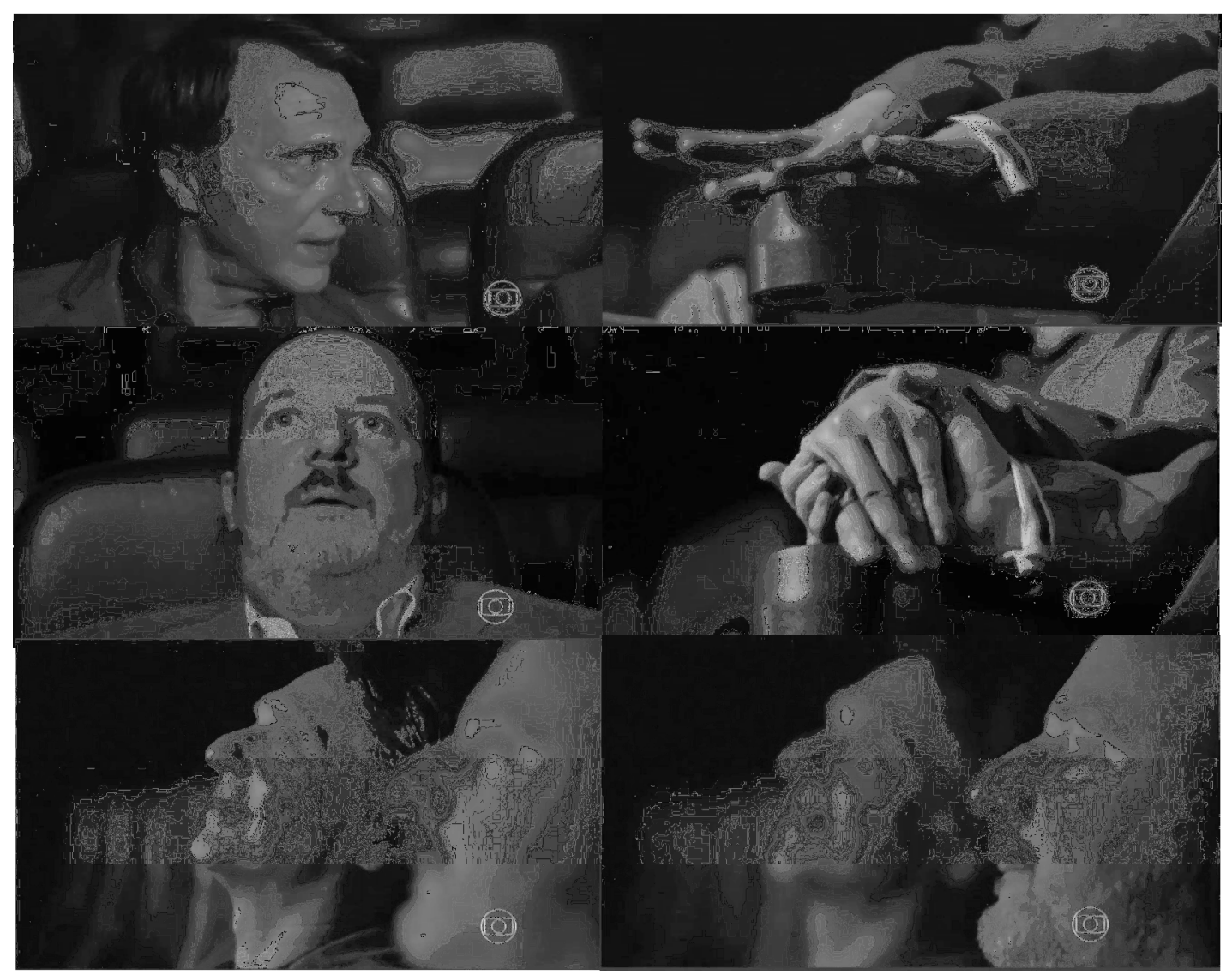

Figura 08: Recortes de partes da Cena 02.

Fonte: Sete Vidas, Cap. 106, TV Globo, 2015. 
REVISTA X, Curitiba, volume 14, n.4,p. 158-183, 2019

Como descrito, nesses recortes da cena, Renan coloca a mão sobre o braço e logo sobre a mão de Eriberto, que abre os dedos para o entrelaçamento. Com esse movimento, Renan constrói para si e para o amigo que ele é desejado, não bastando a contemplação; é preciso o toque, o prazer. Ao avançar nesse alinhamento, ele sabe/espera que não haverá recusas por parte de Eriberto. Ele está certo. De pronto, a resposta de Eriberto é a de abrir seus dedos para o entrelaçamento. É a performatização do desejo, a performatização de si como homens que podem e sentem afetos, carinhos, desejos e prazer com outro homem. Fez-se necessário o uso do recurso tacêsico (DIONÍSIO, 2005). Assim, entendemos que, do interesse, Renan e Eriberto foram à "prática", ao toque, ao prazer, construindo o desejo, construindo-se a partir do prazer. Com a abertura dos dedos e a inserção para o entrelaçamento, os dois agora produzem no corpo que são mais que amigos, a partir dessa construção metafórica do intercurso sexual, da penetração. É a expressão de subversão à heteronorma na dimensão da sexualidade.

Eriberto, por sua vez, expressa certo medo na expressão facial, que se efetiva porque engole a saliva, como em um gesto de que algo estava obstruindo a passagem em sua garganta. Seria a ausência da enunciação verbal? Certamente não, pois essa não se fez necessária para os sentidos de desejo e prazer que eles construíram. Em resposta, Renan olha para o amigo. É a sinalização de que há apoio e companhia entre eles, tal como já falaram na cena 02.

Suas mãos se entrelaçam mais fortemente. Dessa vez, é Renan que engole a saliva, mas apresenta calma no semblante. Dessa interação, as mãos se tocam, voltam a se entrelaçar e se apertam. Um leve sorriso e uma expressão de paz são construídos em seus semblantes. O olhar deles é lançado para o horizonte. O que está acontecendo nessas partes da cena? Que citações foram realizadas? Que performatização está sendo construída por Eriberto e Renan?

É certo afirmar que Renan e Eriberto corporificam afastamento do desejo afetivo e sexual e do prazer considerados normais aos homens dentro dos marcos regulatórios considerados aceitos de nossa cultura sexual. Nessa, a heterossexualidade é imperativa, pois aos homens estariam o desejo e o prazer direcionados ao sexo oposto. Os olhares, os maneios de cabeça, os suspiros, os sustos, os semblantes calmos, os sorrisos leves e o entrelaçamento de mãos produzem linguagem e a linguagem está produzindo desejos sexuais e afetivos transitivos, subversivos, indecentes; estão construindo o afeto e o prazer entre homens em fase adulta. Logo, se cogitarmos uma nova cena, 4, entre eles, 
REVISTA X, Curitiba, volume 14, n.4,p. 158-183, 2019

um novo encontro, é certo que seus desejos teriam colocado seus corpos em um intercurso sexual e o gozo da relação em todas suas possibilidades. Agora, são mais que amigos. São namorados ou companheiros em uma nova vida, ou como queiram se reconhecer. São amantes!?! No tocante ao gênero, não se configuram como aqueles homens que gritam "aí que delícia ser viado", "toda gatinha" e "toda afeminada". São homens ("tradicionais") em derivas sexuais.

\section{Cena de TV: dispositivo de educação da sexualidade e de gênero}

No tocante à compreensão das interações entre Renan e Eriberto serem cenas de uma telenovela, entendemo-las como dispositivo pedagógico de educação sexual, pois visa recontextualizar os sentidos produzidos acerca das sexualidades masculinas consideradas desviantes, interpelando seus interlocutores e interlocutoras. Quer que se compreenda como válidos esse modo de se reconhecer enquanto homens e viver os afetos, desejos e prazeres, em masculinidades em derivas. A faixa etária de seu público é a partir dos 10 anos. Logo, compreendemos a escolha da sutiliza e da delicadeza com as quais as cenas foram construídas, visto que os afetos, desejos e prazeres entre eles não são explícitos, mas subentendidos, pois provavelmente a produção da telenovela deve estar preocupada em não sofrer constrangimentos devido à discussão acerca de sexualidade e gênero, tal como sofreu a loja com seu outdoor, caso mencionado nesse texto.

Poderíamos numa discussão mais ampla, refletir sobre a sintaxe televisiva, processo de construção e seus elementos (SANTOS FILHO, 2016), seja sintaxe horizontal, os enquadramentos, quase praticamente todos em closes, que normalmente propõe "mostrar" a emoção, ou a sintaxe vertical, em que as imagens são exibidas ao som de "Blowin' in the wind" (Soprando ao vento), de Bob Dylan, a exemplo do trecho “quantas estradas um homem precisará andar até que possa ser chamado de homem?". Mas, em decorrência do espaço de discussão, não o faremos aqui. Nossas considerações são as de que essas cenas televisivas são sim subversivas, pois performatizam/validam outras compreensões acerca dos afetos, desejos e prazeres entre homens. É a telenovela dando-nos lições de sexualidade (e gênero), de modo a desconstruir perspectivas conservadoras, produzindo, assim, visibilidades e fomentando espaços de (r)existências dissidentes. 
REVISTA X, Curitiba, volume 14, n.4,p. 158-183, 2019

\section{CONSIDERAÇÕES ACERCA DA LEITURA EM PERSPECTIVA QUEER: LINGUAGEM E SEXUALIDADE}

Nessa leitura, assumimos uma perspectiva de estranhamento da relação linguagem e sexualidade. Mas, o que é essa postura queer nos estudos linguísticodiscursivos? Nessa reflexão, a partir de Kulick (2000), que vamos além de estudos de uma suposta linguagem gay ou lésbica, de homens ou mulheres. Essa compreensão se sustenta pela problematização da noção de língua(gem) e de sexualidade, não mais vistas pelo viés essencialista. A linguagem não é mais pensada como fundada e exclusiva de determinada identidade sexual, por exemplo.

No viés da relação "linguagem e sexualidade", como aqui desenvolvemos, para Kulick (2000) devem ser tomados os fenômenos que compõem a sexualidade como "objetos de estudos", tais como o desejo, o prazer, como apresentamos em nossa leitura. A proposta é a de compreender esses fenômenos sendo forjados em língua(gem) incorporada. Nessa necessidade conceitual e procedimental, saímos da noção de sexualidade como identidade autoproclamada simplesmente, tomada como intransitiva. Também, conforme explica, não basta afirmamos que sexualidade (ou gênero) é construído; é necessário "mostrar" o que é realizado como sexualidade (ou gênero) a partir dos fenômenos de sua constituição. Nessa área de estudos linguísticos, a Linguística Queer, a investigação é para compreendermos como as pessoas constroem $o$ senso de quem são e como as semioses (corporificadas) são empregadas, como o sujeito/corpo produz-se e produz o outro, produzindo linguagem, e de como produzem o senso de quem o(a)s outro(a)s são. A sexualidade de Renan e Eriberto, dois homens adultos em processos iniciais de derivas sexuais, está composta de muitos aspectos, tais como alegrias, medos, desejos, prazeres. Não é apenas a identificação sexual. Essa é constituída desses aspectos mencionados. É um processo complexo.

Em nossa leitura, pensar a relação linguagem e sexualidade perpassou pela reflexão da relação linguagem e desejo, focalizando práticas semióticas culturalmente fundamentadas. Por essa perspectiva, o desejo não é individual, mas sociocultural, construído em processos de iterabilidade, ("processo de citação"), no sentido de que "recirculam" na vida social (por isso reconhecíveis, mesmo que sejam outros, recontextualizados). Tem historicidade. Dessa maneira, passamos a compreender que os processos internos só ganham vida na exteriorização, nas práticas construídas através das atividades discursivas (BILLING, 1997 apud KULICK, 2000), que constroem os 
REVISTA X, Curitiba, volume 14, n.4,p. 158-183, 2019

processos internos, a exemplos dos afetos, desejos e prazeres. Corroborando essa compreensão, entendemos com Miskolci (2017) que o desejo sexual, entendido como interesses, é moldado nas interações sociais. É situado, não determinado, não assujeitado, tampouco puramente biopsicológico.

Por fim, nesse processo de leitura queer, precisamos compreender que "assim como os corpos produzem a linguagem (...) a linguagem produz os corpos". Esse entendimento é útil para pensarmos em processos semióticos de indexicalidade (BUCHOLTZ e HALL, 2016), que visam performatividades de sexualidade (e de gênero).

De que modo essa postura queer favorece às práticas e ou vivências/experiências no atual contexto? Essa postura de "estranhamento", problematização, da relação língua(gem) e sexualidade se faz necessária para compreendermos a participação dos enunciados na luta discursiva em torno das sexualidades, por exemplo. Nas leituras com essa postura, construímos saberes sobre a vida social em imbricamento às práticas discursivas, tal como fizemos acerca dessas cenas da telenovela e seus propósitos discursivos nesse contexto atual de luta sobre e entre sujeitos e suas sexualidades, principalmente as consideradas desviantes.

\section{REFERÊNCIAS}

AUSTIN, J. L. Quando dizer é fazer: palavras e ação. Porto Alegre Artes Médicas, 1990 [1962].

BIZZOCCHI, Aldo. Partículas elementares. Revista Língua. 2014, p. 44-45.

BUCHOLTZ, Mary; HALL, Kira. Embodied Sociolinguistics. In. Nikolas Coupland. Sociolinguistics: theoretical debates. Cambridge; Nova Iorque: Cambridge University Press, 2016, p. 173-200.

BUTLER, Judith. Problemas de gênero - feminismo e subversão da identidade. Rio de Janeiro: Civilização Brasileira, 2003 [1990].

Performatividad, precariedad y politicas sexuales. AIBR. Revista de Antropologia Iberoamericana, v. 04, nº 03, set/dez 2009, p. 321-336.

COLLING, Leandro. O que perdermos com os preconceitos? Cult - Dossiê ditadura Heteronormativa, $\mathrm{n}^{\circ} 202$, ano 18,2015 , p. 22-25.

DIONÍSIO, Ângela Paiva. Multimodalidade discursiva na atividade oral e escrita. In: MARCUSCHI, Luiz Antônio; DIONÍSIO, Ângela Paiva (Orgs.). Fala e escrita. Belo Horizonte: Autêntica, 2005. p. 177-204. 
FABRÍCIO, Branca Falabella; MOITA LOPES, Luiz Paulo da. "A guerra dos carneiros gays": a (re)construção do fantasma da eugenia sexual no discurso midiático. In Matraga, Rio de Janeiro, v.15, $\mathrm{n}^{\circ}$ 22, jan/jun/2008, p. 64-68.

FOUCAULT, Michel. História da sexualidade 1 - a vontade de saber. Rio de Janeiro: Edições Graal, 1988.

GOFFMAN, Erving. Footing. In. Branca Ribeiro Telles e Pedro M. Garcez (Org.). Sociolinguística Interacional. São Paulo: Edições Loyola, 2002 [1979], p. 107-148

GOFFMAN, Erving. A situação negligenciada. In. Branca Ribeiro Telles e Pedro M. Garcez (Org.). Sociolinguística Interacional. São Paulo: Edições Loyola, 2002 [1964], p. 13-43.

KULICK, Don. Gay and lesbian language. Annual Review of Anthropology, vol. 29, p.243-283, out., 2000.

LEWIS, Elizabeth Sara; BORBA, Rodrigo; FABRÍCIO, Branca Falabella; PINTO, Diana de Souza (Org.). Queering Paradigms IVa - insurgências queer ao Sul do Equador. Peter Lang AG, International Academic Publishers, Bern, 2017.

LIVIA, Anna; HALL, Kira. Queerly Phrased: language, gender and sexuality. New York: Orford University Press, 1997.

LOURO, Guacira Lopes. Um corpo estranho - ensaios sobre sexualidade e teoria queer. Belo Horizonte: Autêntica, 2008.

MISKOLCI, Richard. Desejos digitais - uma análise sociológica da busca por parceiros on-line. Belo horizonte: Autêntica Editora, 2017.

MISKOLCI, Richard. O que é o Queer? In. I Seminário Queer. Youtuber. Disponível em < https://www.youtube.com/watch?v=X0TbtqqU0MI > Acesso em 27 de abril de 2017.

MOITA LOPES, Luiz Paulo da (Org.). Por uma linguística aplicada indisciplinar. São Paulo: Parábola Editoria, 2006.

MOITA LOPES, Luiz Paulo da; BAYNHAM, Mike. Introduction. In. Luiz Paulo da Moita Lopes; Mike Baynham (Org.). Meaning making in the periphery. AILA Review, vol. 30, 2017, p. v-xxii.

PELÚCIO, Larissa. Um flerte com a normalidade [Prefácio]. In. Richard Miskolci. Desejos digitais - uma análise sociológica da busca por parceiros on-line. Belo Horizonte: Autêntica Editora, 2017, p. 11-16.

PRECIADO, Beatriz. Multidões queer: notas para uma política dos "anormais". Estudos feministas, vol. 19, n. 2, 2011, p. 11-20.

SANTANA, André. Há dois anos, a novela Sete Vidas chegava ao fim. Observatório da televisão. 2017. Disponível em < encurtador.com.br/duIJ0 >. Acesso em dezembro de 2018. 
REVISTA X, Curitiba, volume 14, n.4,p. 158-183, 2019

SANTOS FILHO, I. I. A construção de masculinidades bissexuais em salas de batepapo: um estudo em linguística queer. 2012. 250f. Tese de Doutorado. Universidade Federal de Pernambuco, Recife, PE, Brasil, 2012.

Linguística queer: para além da língua(gem) como expressão do lugar do falante. In. SILVA, A. P. D. (Org.). Escrit@s sobre gênero e sexualidades. São Paulo: Scortecci, 2015a. p. 15 -28.

Da emergência da Linguística Queer. Seminário de Pesquisa: Introdução à Linguística Queer. Programa de Pós-Graduação em Letras. Maringá: UEM, mimeo, 2015b.

Fala II: modos de uso da língua - multimodalidade. In. Ismar Inácio dos Santos Filho. Leitura e produção de texto IV. Natal: EDUFRN, 2016, p. 93-128.

Linguística queer: na luta discursiva, como/sobre prática de ressignificação. In. Silva, D. C. P.; Melo, I F; Castro, L. G. F. (Orgs.). (Org.). Dissidências sexuais e de gênero nos estudos de discurso. Aracaju: Criação, 2017. p. 153 - 184. 